慶應義塾大学学術情報リポジトリ

Keio Associated Repository of Academic resouces

\begin{tabular}{|c|l|}
\hline Title & $\begin{array}{l}\text { Genetic identification and detection of human pathogenic Rhizopus species, a major } \\
\text { mucormycosis agent, by multiplex PCR based on internal transcribed spacer region of rRNA gene. }\end{array}$ \\
\hline Sub Title & ムーコル症の主病原菌、Rhizopus属のmultiplex PCR法を用いた同定および検出 \\
\hline Author & 永尾, 圭介(Nagao, Keisuke) \\
\hline Publisher & 慶應医学会 \\
\hline Publication year & 2005 \\
\hline Jtitle & 慶應医学 (Journal of the Keio Medical Society). Vol.82, No.2 (2005.6),p.37- \\
\hline JaLC DOI & \\
\hline Abstract & \\
\hline Notes & 号外 \\
\hline Genre & Journal Article \\
\hline URL & https://koara.lib.keio.ac.jp/xoonips/modules/xoonips/detail.php?koara_id=AN00069296-2005060 \\
& 2-0037 \\
\hline
\end{tabular}

慶應義塾大学学術情報リポジトリ(KOARA)に掲載されているコンテンッの著作権は、それぞれの著作者、学会または出版社/発行者に帰属し、その権利は著作権法によって 保護されています。引用にあたっては、著作権法を遵守してご利用ください。

The copyrights of content available on the KeiO Associated Repository of Academic resources (KOARA) belong to the respective authors, academic societies, or publishers/issuers, and these rights are protected by the Japanese Copyright Act. When quoting the content, please follow the Japanese copyright act. 


\section{Genetic identification and detection of human pathogenic Rhizopus species, a major mucormycosis agent, by multiplex PCR based on internal transcribed spacer region of rRNA gene. （ムーコル症の主病原菌、Rhizopus属のmultiplex PCR法を用いた同定および検出）}

\section{永尾圭介}

\section{内容の要旨}

[目的］ムーコル症は真菌による日和見感染症で、死後剖検にて診断 されることが多い。本研究の目的は、主要病原菌Rhizopus属のmultiplex PCR法での同定と臨床検体からの遺伝子検出を行うことである。

[材料・方法] 以下のRhizopus属 5 菌種を対象とした : $R$ oryzae, $R$. azygosporus（RA）、R. microsporus (RM) var. microsporus (RMM)、 var. oligosporus (RMO) 、 var. rhizopodiformis (RMR) 、R. stolonifer、 $R$. schipperae. rRNA遺伝子ITS領域の塩基配列を決定し、特異的プライ マーを作成した。PCR法はmultiplex PCR法で行った。菌種の相違は走 查型電顕 (SEM) にて確定した。臨床応用として皮膚ムーコル症 3 例 より分離させた菌株、検体（病理組織切片 3 例、血清 1 例）を使用し た。

[結果］Rhizopus属 5 菌種に対して 4 ペアの特異的プライマーを作成 することが出来た。RAとRMのITS領域および表現型は極めて類似し ており、これらは同じプライマーセットで同定した。Multiplex PCR法 を試行したところ、一度の反応で菌種の鑑別を行うことが出来た。 RA とRMが鑑別できなかったため、詳細な塩基配列の解析を行ったとこ ろ、RAのITS領域には特徵的な遺伝子多形が数籄所存在することが分 かりこれらは塩基配列で鑑別することが可能であった。臨床分離株 3 株についても検討を加えた。その結果、R. oryzae ( 2 株)、RA/RM (1 株）と同定し、SEMによる形態学もこれに合致するものであった。臨 床検体として、皮膚ムーコル症のパラフィン切片 3 例、血清 2 本を PCR法にて評価したところ、それぞれ分離株に合致した菌種の遺伝子 が検出された。

[考案と結語] RAとRMはSEMやPCR法で区別することが出来なかっ たが、RAの塩基配列には特徴的な遺伝子多型が存在し、それぞれの配 列はRMMかRMRと完全に一致していた。RMMとRMRの交配でRA様 の株が得られることより、RAはRMの変種間交配より生じたものと推 測されている。本研究の結果もこれを支持するものであった。過去の PCR法によるRhizopus属の同定は $18 \mathrm{~S} \cdot 28 \mathrm{~S}$ rRNA遺伝子などを用い、 2 菌種のみで成功している。本研究では変異に富むITS領域を標的にし、 Rhizopus属 5 菌種を 4 つに区別することができた。アスペルギルス症 でも報告されているとおり、血清を含めた臨床検体にて真菌遺伝子を 検出することが出来たことはPCR法が菌株の同定のみならず、スク リーニング法としての可能性が示唆された。

\section{論文審査の要旨}

本研究は、日和見感染症であるムーコル症の主要病原菌である Rhizopus属のmultiplex PCR法による同定と検出を試みたものであ る。すなわち、人に病原性を示したことのあるRhizopus属 5 菌種を 研究の対象とし従来からの胞子贵胞子の走查型電子顕微鏡 (SEM) による観察と真菌のrRNA遺伝子ITS (internal transcribed spacer) 領域 を増幅し塩基配列を決定する方法を用いた。得られた塩基配列およ びGenbankに登録されているデータより各菌種に対する特異的プライ マーを設計した。胞子囊胞子の形態は概ね過去の記載と合致するも のであった。しかし、形態およびITS 領域の塩基配列では $R$ microsporusとR. azygosporusを鑑別することができず、これらに関し ては同一のプライマーで同定を行った。5 菌種に対して作成した 4 セットのプライマーを混合し、 multiplex PCR法を行ったところ、一 度の反応で対象菌種を同定することができた。臨床分離株に応用 し、形態学的所見と合致する結果を得た。ムーコル症 3 例からの臨 床検体（病理組織切片および血清）についても検討したところ病理 組織切片から各分離菌と合致するPCRの結果を得ることが出来た。 ある症例では未治療時、ならびに治療後の血清を得ることができ、 その両方からRhizopus属の遺伝子を検出することが出来た。血清か ら真菌遺伝子を検出出来たことから、今後PCR法が内臓ムーコル症 などのスクリーニングにも応用出来る可能性が示唆された。本研究 ではR azygosporus とR. microsporusをPCR法で鑑別することは出来な かったが、詳細な遺伝子解析でR. azygosporusの特徴的な遺伝子多型 はこの菌種が $R$. microsporus var. rhizopodiformis と $R$. microsporus var. microsporusの自然界で交配したことによって生じた可能性が示唆さ れた。

審査ではまず真菌感染症の分子生物学的手法による原因菌同定の 意義が問われた。近年抗真菌剤の開発も積極的に行われており、類 似した病態を示しうるAspergillus属と接合菌属は薬剤感受性が異なる ため、同定は適切な治療戦略を組み立てる上で必要と回答された。 また、菌種レベルまで鑑別することは現段階で治療戦略におよぼす 影響は少ないが、今後臨床分離株に対する薬剤感受性の確認を行う 必要がある。さらに、臨床検体より真菌遺伝子を検出したことは臨 床上有意義なことであるが、検討出来た血清が 1 症例のみだったこ とを指摘された。疾患の稀さ故に今後症例の蓄積と多くの血清で検 討することが今後の課題であると回答され了解された。R. azygosporusの特徴的な遺伝子多型についても興味深い現象である が、このような現象が他の微生物で知られているかが問われた。現 在のところ、ある菌種の亜種同士が交配し、安定した菌種が得られ ている可能性があるのは今回報告したR. azygosporusのみであると回 答された。

以上のように、本研究には今後さらに検討すべき点を残しているも のの、診断が困難な深在性真菌感染症であるムーコル症ならびにその 原因菌同定に関して新しい分子生物学的手法が診断に導入しうる可 能性を検討した研究として意義あるものと評価された。

論文審查担当者 主查 皮虞科学 西川 武二

微生物学・兔疫学 石川博通 微生物学・兔疫学 小安 重夫 内科学 池田 康夫

学力確認担当者 : 北島 政樹、石川 博通 審查委員長 : 石川 博通 